\title{
Clinical Review on the Main Pathologies Related To the Nuclear Envelope
}

\author{
Herica Morais da Silva, Dara Dos Santos Souza, Magno De Oliveira, Wolney Jácomo, Isabela \\ Maria Agustini da Silveira Bastos, Augustus Caeser Franke Portella, Talita Pereira de Sousa \\ Ferreira, Dalmarcia de Souza Carlos Mourão, Marcos Vinicius Giongo Alves, Aloísio Freitas \\ Chagas Junior
}

\begin{abstract}
The study on the nuclear envelope has become of great importance in scientific research in a multidisciplinary way. The nuclear blade gains more space in research for having a directrelation ship in the development of a typical genetic diseases, attributed as laminopathies. Nuclear laminaria have architecture with diverse attributions, consequently grants mechanical and support actions, stabilizes and organizes the chromatin, during the process of DNA replication, RNA synthesis and the balance of gene expression. These multiplicities of processes denote that genetical terations influence with great expression, as can beseen in Laminopathies. The methods used for this work were based on the methodology of the article Experimental Planning Factorial: Abrief Review of (OLIVEIRA et al., 2018). As a result of the studies made, a wide range of diseases, little known, was mad eexplicit. That previously had hardly their roots of emergence associated with apart, considered untilth enlittle important in the scientifics cope of the cellular studies, like the Nuclear envelope. In this way, one can attribute the emergence of distinct pathologies, which are manifested in different parts of the body, including muscular, cardiovascular, subcutaneousa diposetissue among others. With such advances on the nuclear envelope, and on its importance in disease development, there is the opportunity of discoveries of new forms of medical treatments and prevention methods (possible), this realistic basis is toosubstantial.
\end{abstract}

Index Terms - Nuclear envelope, Mutations, Diseases.

Herica Morais da Silva, Laboratory of plant ecophysiology, Federal University of Tocantins, Chácara 69-72 - Rua Badejos, Lote 7, s/n - Jardim Cervilha,, Gurupi, 77404970, Tocantins, Brazil.

Dara Dos Santos Souza1, Laboratory of plant ecophysiology, Federal University of Tocantins, Chácara 69-72 - Rua Badejos, Lote 7, s/n - Jardim Cervilha,, Gurupi, 77404970, Tocantins, Brazil.

Magno De Oliveira, Laboratory of plant ecophysiology, Federal University of Tocantins, Chácara 69-72 - Rua Badejos, Lote 7, s/n - Jardim Cervilha,, Gurupi, 77404970, Tocantins, Brazil

Wolney Jácomo, EAD- Public Administration, Federal University of Tocantins, Palmas, Tocantins, Brazil

Isabela Maria Agustini da Silveira Bastos, Laboratory of plant ecophysiology, Federal University of Tocantins, Chácara 69-72 - Rua Badejos, Lote 7, s/n - Jardim Cervilha,, Gurupi, 77404970, Tocantins, Brazil. Augustus Caeser Franke Portella, Federal University of Tocantins, Chácara 69-72 - Rua Badejos, Lote 7, s/n - Jardim Cervilha, Gurupi, 77404970, Tocantins, Brazil

Talita Pereira de Sousa Ferreira, Federal University of Tocantins, Chácara 69-72 - Rua Badejos, Lote 7, s/n - Jardim Cervilha, Gurupi, 77404970, Tocantins, Brazil

Dalmarcia de Souza Carlos Mourão, Federal University of Tocantins, Chácara 69-72 - Rua Badejos, Lote 7, s/n - Jardim Cervilha, Gurupi, 77404970, Tocantins, Brazil

Marcos Vinicius Giongo Alves, Center for environmental monitoring and management of the Fire (CeMAF). Federal University of Tocantins, Chácara 69-72 - Rua Badejos, Lote 7, s/n - Jardim Cervilha, Gurupi, 77404970, Tocantins, Brazil

Aloísio Freitas Chagas Junior, Federal University of Tocantins, Chácara 69-72 - Rua Badejos, Lote 7, s/n - Jardim Cervilha, Gurupi, 77404970, Tocantins, Brazil

\section{INTRODUCTION}

Highlight The nuclear lamina (Figure 2) is a protein mesh that coats the inner nuclear membrane nucleoplasmic face and represents an important determinant of interphase nuclear architecture [1]. Eukaryotes typically organize your genome in a separate compartment, the core, which is surrounded by nuclear wraps, such as a barrier. Ruptures of the nuclear chromatin and wrap threaten cell viability and genomic instability. Even with all the assigned process, nuclear wrap focuses on morphological changes, more visible during mitosis. Here, boils down a current understanding of the dynamics of nuclear and wrap your changing relationship to the endoplasmic reticulum $[2,3]$.

It discusses as the nuclear envelope is reformed to insert in your double-membrane structure, core transport ports and nuclear pore complex. The nuclear pores are structures which integrate the nuclear envelope during interphase of mitosis that follows divergent paths seen by microscopy. Both routes ensure that your pores are formed in nuclear wrap connect the cytoplasm and nucleoplasm [4].

The nuclear envelope has a complex organization consisting of internal and external nuclear membranes, nuclear pore complexes, and the nuclear lamina. Membrane complexes and of double pores are easily evident in all eukaryotic cells by conventional electron microscopy, while the blade is often visible only after nuclear subfraction. Most of the cells of the outer membrane have Ribosomes attached and display both continuities, and smooth endoplasmic reticulum, which is functionally similar. The space, present between the nu- clear membranes, called Peri nuclear space directly continuous with the lumen of the endoplasmic reticulum (RER). The inner and outer membranes are joined in complex nuclear pores are large supramolecular structures that provide molecular exchange channels among the cytoplasm and the nucleus. Recent studies suggest that the pore complex houses proteins and RNAs between the cytoplasm and the nucleus for vector processes highly selective, which raises the possibility in which the direct role of regulation and expression of the gene is related to the pore complex nuclear. Another important function of the nuclear envelope refers to the Organization of the nuclear architecture $[1,5]$.

The nuclear envelope is a lipoprotein separation and structure, for your time involves the nucleus and cytoplasm of cells (Figure 1). This structure is composed of the foreign nuclear membrane, the inner nuclear membrane, the nuclear 
pore, and nuclear lamina. The outer nuclear membrane stretches with sturdy acid of the endoplasmic reticulum (RER). The inner nuclear membrane contains a set of transmembrane proteins, among which are the MAN1, the blade collar (B), the associated polypeptide of (Blade) type 1 (LAP1), the LAP2. These proteins allow your nuclear lamina at UNION, also called, inner blade, and your part is located in the nucleus $[1,5,6]$.

The cell cycle comprises a chain of events that come from the formation of the cell to cell division or apoptosis, and this process is strictly regulated because otherwise, it can trigger the development of diseases. This process comprises in mitosis and meiosis, in which, are responsible for cellular renewal, tissue regeneration and confuses parts of the body; and act on formation of ova and spermatozoa, respectively [1, $2,5]$.

The mitotic process of (beginning) of any cell $2 \mathrm{n}$, cells that comprise 46 chromosomes. Then the period of interphase in which occurs the above material. This process is continuous, however, is divided into 4 threads: $1^{*}$ Prophase, $2^{*}$ Metaphase, $3^{*}$ Anaphase e $4 *$ Telophase. After the segment $1 *$ Prophase, we obtain the stages of mitosis. Following $2 *$ Metaphase the chromosomes spiralization centralize in the cell, in the equatorial plane, attached to the spindle fibers.

The thread $3 *$ How- ever, there is a shortening of the spindle fibers, the sister chromatids, moved on opposing poles in the cell. At the end of the previous processes the thread $4 *$ Telophase, diploid cells $(2 \mathrm{~N})$, is formed, similar to the parental cells throughout the whole process. At the end of the previous processes the thread $4 *$ Telophase, diploid cells $(2 \mathrm{~N})$, is formed, similar to the parental cells of the whole process. In this follow up $4^{*}$, If ends the synthesis of mitosis (Division of the nucleus) restarting the process of cytokinesis (equivalent distribution of cytoplasm). In this thread there is a desespiralization of the chromosomes, the nu- clear envelope and nucleolus organoid become evident.

In mitotic synthesis, suggests that the process of haploid cell synthesis (n), have 23 chromosomes. In the meiotic process, following in stages, showing a second process of sequential steps: the first step focuses the Prophase I, metaphase I, anaphase I and telophase I. In the second step, sequential, proceeds to Prophase II, metaphase II, anaphase II telophase II $[1,2,5]$.

Second Kierszenbaum e Tres (2016) [1], differs, the mitotic and meiotic process, not only by the haploid cell synthesis, and Yes, also by analysis in the Prophase I leptotene, zygotene presents as substrings, pachytene, diplotene. The study on the nuclear Envelope has become of great importance in scientific research of multidisciplinary way. The nuclear lamina, WINS more research space by having a direct relationship in the development of atypical diseases, genetic, assigned as laminopathies. Laminaria has a nuclear architecture with various assignments, consequently mechanical and support assignments, stabilize and organize the chromatin during the process of DNA replication, RNA synthesis, and gene expression. These Multiplicities are processes that influence genetic changes with great expression, like a note in Laminopatias [7].

The nuclear envelope, now part of its mysteries unraveled became great object of scientific curiosity since seems to have direct action on formation of hereditary diseases linked nuclear lamins in numerous parts of the body tissues human, although there is a new light on your importance to the functioning of the cells your real paper and the details of the suit, are still in the initial stage of studies, as well as your relationship with regard to pathologies $[1,2,5]$.

In recent years a variety of impressive monogenetic diseases is attributed to mutations in the genes that code for proteins and nuclear proteins wrap's intermediate type of blades. Examples of these diseases are: dilated cardiomyopathy with muscular dystrophy, lipodystrophy, familial partial, Dunnigan type a disease Charcot Marie Tooth type 2, mandibuloacral dysplasia syndrome of Hutchinson-Gilford progeria, called envelopatias or laminopathies nuclear, studies are done about the above comes to generate leads on the functions of Nuclear Wrap EN in pathogens and in aging human. Data on these diseases indicate there is evidence of a gradual occurrence process in which cells mechanically stressed suffer at first, chromatin damage and nuclear wrap, developing minor changes in relation to the transcriptional activation of genes in protective and adaptive segments $[1,8,9]$.

Since 1999, mutations in LMNA demonstrated cause many inherited diseases differ some, like Emery-Dreifuss muscular dystrophy (EDMD) and lipodystrophy familial partial Dunnigan (FPLD), are quite specific to the tissue Others, like the syndrome of Hutchinson-Gilford progeria, caused by a single mutation in the blade (A), are more widespread. Before those discoveries, it was thought that the prevailing functions of the blades (A) and (C) provide mechanical support to the core and anchor the heterochromatin "silent" to the inner nuclear membrane. The findings linking the blades (A) and (C) hereditary diseases have led to a new question: how the mutations in these proteins, expressed in almost all the differentiated somatic cells, cause different diseases, some of which may be specific to fabric $[8,10]$.

According to Mounkes et. Al., (2003) [11], most hereditary diseases are linked to mutations in a specific gene.

Sometimes, mutations in two or more different genes result in diseases with a similar phenotype. Different mutations in the same gene rarely result in a multiplicity of distinct disease unrelated to each other. In the last three years, different mutations in the LMNA gene that encodes the type blades have shown to be associated with at least six different diseases. Research and testing in order to finish as Act these mutations of proteins are made with very hard to try to put an end to the questions around these processes, both interests comes from the impressive features of these mutations, in which a single gene encodes proteins causing several specific diseases of the tissues, it launches, indisputable assumptions about the structure and behavior of the nucleus of the cell [1, $5,11]$.

George Beadle and Edward Tatum, 1941 [12] created a chance that became known as the theory of "one gene-one enzyme", later changed to "a gene onepolipeptídeo". Who claimed that genes Act through the onepolipeptídeo production where each gene produced a single onepolipeptídeo running the particular step in the path ametabolic. This principle gave rise to your similar "one gene-one disease", today such statements are not correct, and possibly one of the best examples is this multifaceted LMNA 
gene encoder. LMNA blades encoding type was characterized in 1993 and subsequently mapped on the chromosome $[1,13]$. The first disease diagnosed in humans,
LMNA-related was autosomal dominant Duchenne muscular dystrophy Emery-Dreifuss [14].

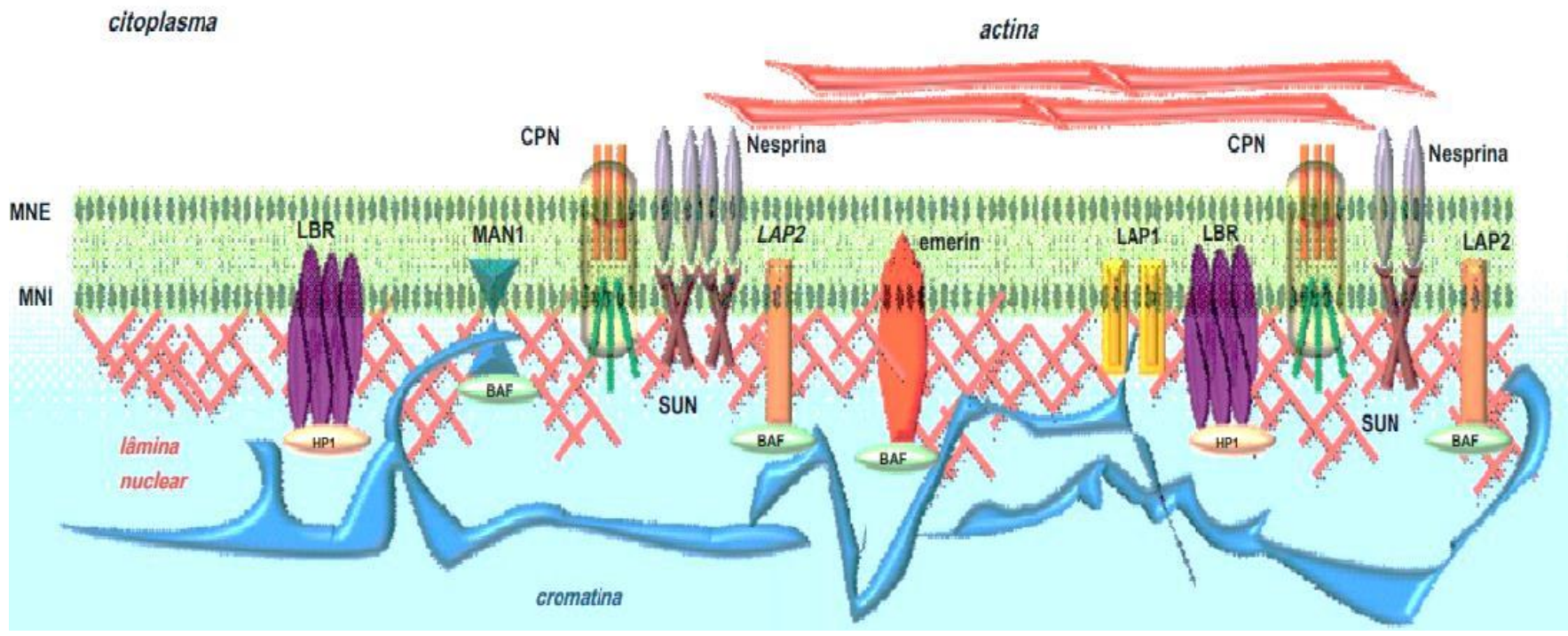

Fig. 1: Source Méndez-Lopes; Worman (2012) [6].

Second Worman et. Al., (2010) [10], monogenic disease caused by mutations in genes that encode type B blade and proteins that are directly or indirectly associated with the nuclear lamina, are also sometimes referred to as laminopathies or envelopatias. The Emery-Dreifuss muscular dystrophy proved to be inherited in a way linked to the $\mathrm{X}$ chromosome, this pathology is related to autosomal hereditary with the X chromosome. Worman et. al., (2010) [10], Reaffirms that the interface of $(\mathrm{EN})$ with this wide range of diseases, which before was not even associated with its functions, is too impressive from a scientific point of view, its mission-related diseases heart muscles and tissues. As for some of the most intriguing syndromes for the medical community, she reflected on the aging carrier Accelerator (Hutchinson-Gilford progeria syndrome). Pathologies caused by LMNA can be observed at different stages of life, however, most of the time your presence is still diagnosed in childhood [7, 15].

Since your discovery in the year 1913, the nuclear envelope has become of great interest by a scientist in the world. Considering that the nuclear lamina won a special mention in the sense is directly connected to the development of rare genetic origin diseases designated Laminopathies. Nuclear lamina has diverse and complex functions, mechanical functions, support, and stability in the Organization of chromatin and DNA replication, in addition, to promote and regulate the RNA gene expressions. These Multiplicities functional show that genetic changes may occur of significant impact, as the Laminopathies, Emery-Dreifuss Muscular Dystrophy specifically (DMED), Lipodystrophy Familial Partial, Leukodystrophy Autosomaldominant adult, and Progeróides Syndromes [7].

EDMD (Emery-Dreifuss muscular dystrophy) is classically characterized by progressive muscle weakness and wasting in scapulo-distribution slowly humeral peroneal, contractures of elbows, ankles, and back of the neck, and dilated cardiomyopathy with atrioventricular block an early start. Contractures are the first clinical signs of the disease and appear in the first decade of life, before muscle weakness and loss. Contractures affecting the elbows, the extensor muscles of the neck and Achilles tendons and avoid full extension, leading to difficulties with posture and walk. The slowly progressive muscle weakness and loss begin in a distribution scapulo- humeral peroneal, usually during the end of the second decade of life $[1,5,14,16]$.

Ad-EDMD, EDMD autosomal dominant these laminopathies represent a heterogeneous group of genetic disorders characterized by mutations in the LMNA gene, which encodes two blades, A and C, by alternative splicing of the primary transcript. The slides belong to the family of multigenic, adjacent to the mesh-like structures, intermediate filaments that form the nuclear lamina, nucleoplasmic of the inner nuclear membrane. They interact with emerina, the proteins encoded by the gene for the form of X-linked EDMD (X EDMD), with several proteins of nuclear and wrap with the chromatin. Although you're wide distribution and your role in nuclear architecture, blade changes a/c are responsible for several very specific disorders, however, very heterogeneous $[1,17]$.

The first Laminopatia was the autosomal dominant Emery-muscular dystrophy Dreifuss (EDMD), a genetic disorder characterized by the clinical triad of early contractures, muscle loss and weakness with a peroneal and error distribution Cardiac conduction defects. The finding that emerina, a protein nuclear LMNA, and inner wrap were both involved in EDMD suggested that the blades can represent specific and relevant factors in heart and skeletal muscle and that the integrity of the nuclear membrane and associated structures are specifically required for muscle function [18-21].

The LMNA gene is the gene responsible for the codification of the blade as the blade (c) located on chromosome 1 (locus 1q-21.2-21.3). Differently type blades 
(B) located on chromosome 5 is encoded by the LMNB gene. The exon 1 of the LMNB gene is responsible for encoding the N-terminal globular domain "head domain". Exons 1 to 6 of the code for the central Rod domain "domain and the exons 7, 8 and 9 code C-terminal globular domain. The Exon 7 has amino acids NLS "Nuclear localization signal", what are amino acids protein transport flags into the nucleus through the nuclear pore complex organization the CPNs. Having the gene LMNB has a total [17, 20, 22].

The 11 and 12 are Exon encoding the blade, and the Caax motif present in pre-blade in the field terminal carboxylic acid, a form not synthesized of the blade, which is encoded in Exon 12. The set of four amino acids having the first Cysteine, with more two aliphatic amino acids and an amino acid is recognized as terminal Caax $(\mathrm{C}=$ cysteine, the aliphatic amino acid, $=\mathrm{X}=$ terminal residue), [23].

This feature is extremely important for post-translational processes, such as the farnesylation, in which a group is added to the residue isoprenyl of cysteine. The prenylation is the addition of a hydrophobic molecule to a protein, and eventually, facilitate the connection to plasma membranes and affecting the location and functional activity of the protein itself [7].

In fact, these post-translational modifications that allow the blade to become mature and properly activate [8]. The enzymes responsible for this change are three: geranyl transferase, Caax farnesyl transferase, and protease. B type blades are constitutively farnesila in to lose the farnesyl group, scheduled to play your role in the nuclear blade [24]. The LMNA gene produces beyond the blade $\mathrm{A}$ and $\mathrm{C}$, two other smaller proteins $A(\Delta) 10$ and $C 2$ by alternative synthesis, express- ing different Laminopathies: from pathophysiology to therapy 10:00 pm development and tissue specificity. Because of the blades, the type only if you find expressed in differentiated cells, it is considered that they should intervene at the level of differential expression genes $[11,20,22,23]$.

The blade $\mathrm{A}$ and $\mathrm{C}$ although share the same amino acid, 566 differ in carboxylic terminal, where the blade has 98 unique and specific amino acids, and the CaaX motif, unlike the blade $(\mathrm{C})$ that does not have the CaaX motif and has in your terminal domain a set of six carboxylic amino acids (VSGSRR) [23]. The explanation of this phenomenon is based on the fact that the messenger RNA which contains the genetic information for the synthesis of the blade (C) graduate through the transcript of LMNA gene only until the Exon 10. The transcript to the Exon 12 happens when the blade is this differential transcription which allows obtaining two different mRNA sizes and there- fore two different proteins after translation Ribosome [25, 26].

The pathology of Charcot-Marie-Tooth disease CMT, the initials is characterized due to your commitment of distal peripheral nerve cells, having a variable in your clinical course. In your evolutionary framework and followed by a distal weakness, decreased the sensitivity of the lower limbs and slow evolution of atrophy. Usually, the reflexes are abolished, which can exalt accompanied by signs of Babinski. In the thirds of the legs, is often the date of atrophies. Through the aid of a nerve conduction studies in pathology demyelinating CMT qualifies in CMT1 and axonal
CMT2 [27].

CMD - dilated cardiomyopathy is the inadequacy of idiopathic myocardial muscle contraction. A pathology of heart muscle literally meaning a disease of the heart muscle, in which the heart is dilated with atrioventricular block are some disturbances arrive to lead to severe ventricular arrhythmias, inadequate heart rate and may lead the patient to death severely [1, 7, 27-31].

To observe the varied and complex interactions responsible for the physiology of the muscle fiber is understood that various mutations in the same gene, can create different phenotypes. As examples, various mutations in the dysferlin gene may manifest as a form of autosomal recessive whose waist Dystrophy (LGMD SUBTYPES 2B); on the other hand, the mutation FKRP gene (related protein) originally associated with congenital muscular dystrophy (MDC1C) described subsequently associated with the waistlines of Duchenne (LGMD2I). In what concerns, defects of distinct proteins result in similar clinical pictures as can be seen in some congenital muscular Dystrophies as part changed functional mechanisms underlying the phenotypic similarity $[1,5,32]$.

This would be an extreme simplification: we now know that mutations in different exons of the gene to a wide variability of phenotypic aspects, being able to express, in addition to both forms of EDMD (autosomal dominant and heteronomous recessive LGMD SUBTYPES-1B), it was thought that mutations in the central domain (domain, Rod) hesitate in dilated cardiomyopathy with conduction disturbances, undisturbed in skeletal muscle, while mutations in the fields of head and hesitate to DM queue Emery-Dreifuss, autosomal dominant form. This would be an extreme simplification: we now know those mutations in different exons of the gene to a wide variability of phenotypic aspects, being able to express, in addition to both forms of EDMD (autosomal dominant and heteronomous recessive LGMD SUBTYPES-1B), dilated cardiomyopathy with conduction defects even partial, Dunningan type lipodystrophy and sometimes absolute normality. The investigation into possible genes segregated modifiers in many affected families, supplemented by the study of single nucleotide polymorphisms (Snp single nucleotide polymorphisms), can probably explain this variability $[7,10$, 33].

\section{MATERIALS AND METHODS}

The methods used for this study were based on the methodology of the article Experimental Planning Factorial: Abrief Review de (OLIVEIRA ET AL., 2018) [34].

\section{RESUlTS AND DISCUSSION}

After the removal of the articles repeated between the different searches, exclusion criteria were applied, as shown in Figure 1. Of the 56 remaining articles were recovered 10 original articles of research on the structure, functio, and pathologies related to the Nuclear Envelope. By means of the manual search were recovered over 5 articles.

Articles for use in this review, after exclusion criteria were related is mapped in a manner homologous with pathologies, 


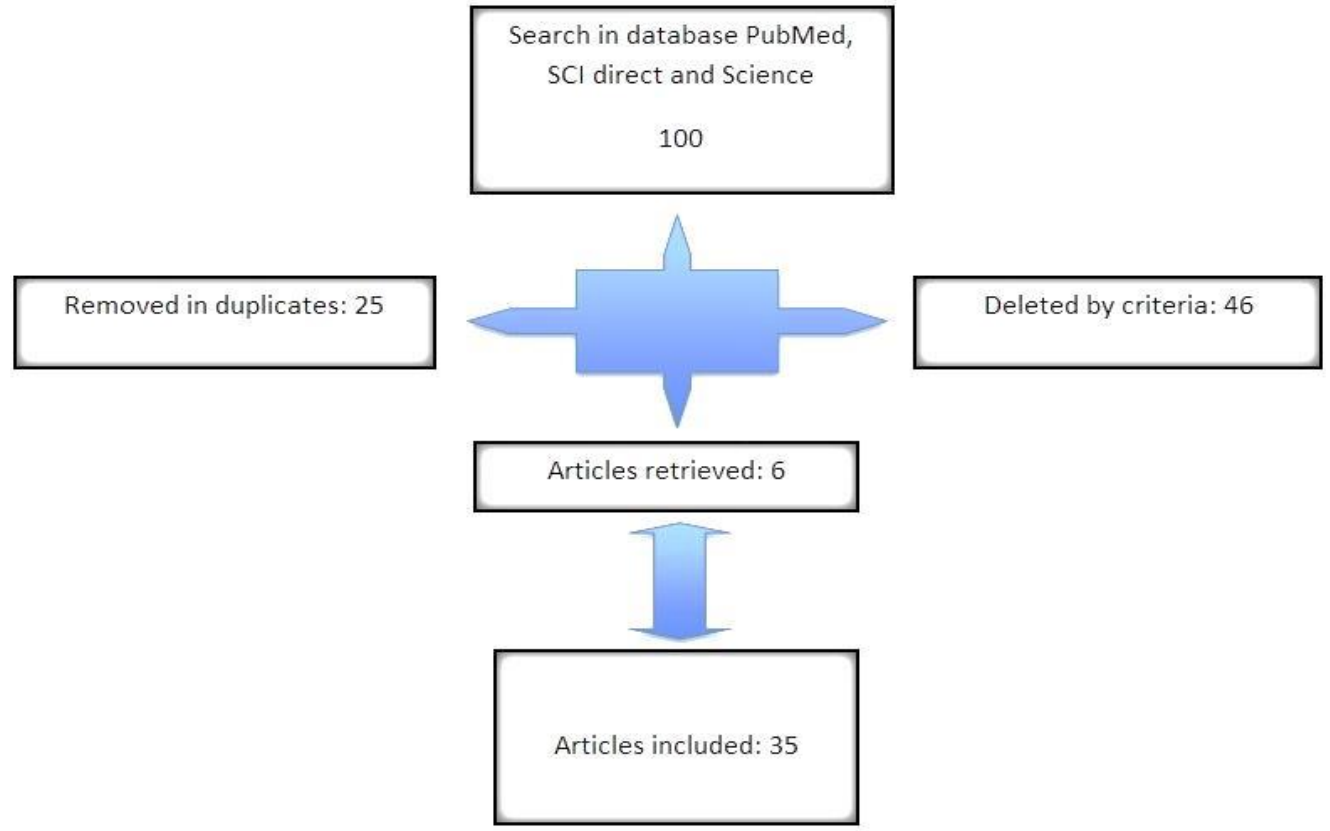

Fig. 2: Flowchart for the identification and selection of articles. (Prepared by the authors, 2018).

considering your source in a multitude of seemingly different diseases relating to wrap proteins nuclear.

As a result of the studies made explicit has a wide range of diseases, little known. That previously would have hardly its roots of emergence associated with a part, considered up to then unimportant in the context of scientific cell studies, such as the nuclear Envelope.

That way, you can assign the emergence of distinct pathologies, which manifest themselves in different parts of the body, including muscle tissue subcutaneous adipose tissue, cardiovascular, among others. With such breakthroughs on nuclear and Wrap on your importance in the development of the disease, there is the possibility of the discovery of new forms of medical treatments and methods of prevention (possible), are realistic base is too substantial.

The following is an illustrative chart shows the frequencies of illnesses that have gained more prominence in the scientific world in being more researched currently, therefore, are the ones that have been manifesting in humans, because of mutations that occur in the genes.
Distrofia Muscular de Emery-Dreifuss

AD-EDMD, EDMD autossômica dominante

CMT2B1, Neuropatia de Charcot-Marie-Tooth tipo 2 B1

DCM, cardiomiopatia dilatada

EDMD, Distrofia muscular de Emery-Dreifuss

LGMD-1B, cinturas musculares tipo distrofia 1B

FPLD lipodistrofia parcial familiar

LBR, Recetor Lamin B
Furthermore, it would not be in any way premature to say that there are great possibilities for the future the number of disorders linked to (EN) will grow even more because the genes that suffer mutations are not always the same and not the cell affected area is restricted to a fixed region only. Considering that many human diseases continue with their origins of birth unknown.

For such findings, was used as the basis of studies and research digital platforms such as online magazines and scientific journals, in addition to medical information, we can report that cited pathologies in table 1 of this work, denotes the possibility according to the authors that their origins are in the Nuclear Envelope.

In table 2, exposes some of the different syndromes caused by the LMNA and bodily regions affected, which has your initial training in nuclear, Wrap in regions affected by them and the authors cited in the course of the study to the creation This review article. According to the authors mentioned in table 2 of this study, these syndromes have origin in the Nuclear Envelope.

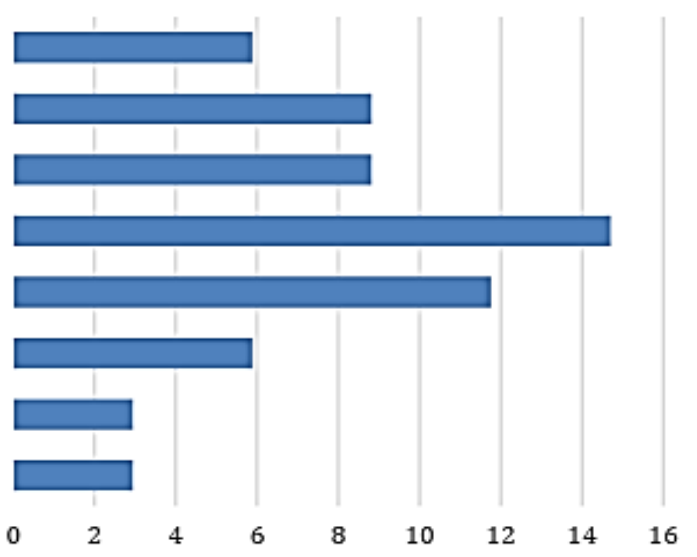

Fig. 3: Graphic/Number of quantitative studies by authors about diseases correlated with protein synthesis of the nuclear envelope. Source: (Prepared by authors 2018). 
Table 1: information containing the relationship between diseases and syndromes and top authors who have researched on the subject.

\begin{tabular}{|c|c|c|c|}
\hline Pathology & Reference & Total & $\%$ \\
\hline Emery-Dreifuss Muscular Dystrophy & $\begin{array}{c}\text { Mounkes Leslie ET AL., (2003) } \\
\text { BONNE; LETURCQ; YAOU, (2015) }\end{array}$ & 2 & 5,88 \\
\hline AD-EDMD, EDMD autosomal dominant & $\begin{array}{l}\text { WORMAN; ÖSTLUND; WANG, (2010) } \\
\text { Bonne; leturcq; yaou, (2015) } \\
\text { Mounkes ET AL., (2003) }\end{array}$ & 3 & 8,82 \\
\hline $\begin{array}{c}\text { CMT2B1, Charcot-Marie-Tooth } \\
\text { Neuropathy type } 2 \text { B1 }\end{array}$ & $\begin{array}{c}\text { Skoko ET AL., (2009) } \\
\text { VALLAT; MAGY, (2010) } \\
\text { A; FIAGA; SAENZ, (2010) }\end{array}$ & 3 & 8,82 \\
\hline DCM, dilated cardiomyopathy & $\begin{array}{c}\text { Yamaki ET AL., (2007) } \\
\text { NUNES ET AL., (2006) } \\
\text { AZEVEDO ET AL., ([s.d.]) } \\
\text { HUEB ET AL., (2001) } \\
\text { PÊGO-FERNANDES ET AL., (2010) }\end{array}$ & 5 & 14,71 \\
\hline $\begin{array}{l}\text { EDMD, Emery-Dreifuss muscular } \\
\text { dystrophy }\end{array}$ & $\begin{array}{l}\text { BORIANI ET AL., (2003) } \\
\text { ERAZO-TORRICELLI, ([s.d.]) } \\
\text { MERCURI ET AL., ([s.d.]) } \\
\text { ÖSTLUND; WORMAN, (2002) }\end{array}$ & 4 & 11,76 \\
\hline LGMD-1B, Muscular dystrophy wraps 1B & $\begin{array}{l}\text { AVANCES; CONTROVERSIAS, (2005) } \\
\text { PERNA; HACKEMBRUCH; LEGNANI, } \\
\text { ([s.d.]) }\end{array}$ & 2 & 5,88 \\
\hline FPLD Family partial lipodystrophy & "MÉNDEZ-LÓPEZ, (2012) & 1 & 2,94 \\
\hline $\begin{array}{c}\text { LBR, Receptor Lamin B } \\
\end{array}$ & PYRPASOPOULOU ET AL., ([s.d.]) & 1 & 2,94 \\
\hline Total & & 21 & 61,76 \\
\hline
\end{tabular}

Source: (Prepared by authors 2018).

Table 2: Laminopathies syndromes and their nuclear structure were the diseases.

\begin{tabular}{||c||c||}
\hline \multicolumn{1}{|c|}{ Syndromes } & Affected areas \\
\hline \hline AD-EDMD, EDMD autosomal dominant; & Scapular and pelvic girdle and cardiac involvement \\
\hline CMT2B1, Neuropatia de Charcot-Marie-Tooth tipo 2 B1; & Muscle tissue \\
\hline DCM, dilated cardiomyopathy; & Cardiovascular tissue \\
\hline EDMD, Emery-Dreifuss muscular dystrophy; & Muscle tissue \\
\hline FPLD Family partial lipodystrophy; & Muscle tissue \\
\hline \hline LBR, Receptor Lamin B; & The subcutaneous adipose tissue of the limbs \\
\hline \hline
\end{tabular}




\section{CONCLUSION}

The nuclear envelope is a complex frame by Phospholipids and proteins (membrane lipoprotein) is that through the pores is to bring about exchanges between the core and the nucleoplasm, and pore count varies with the active stage of the cell.

Currently, this structure is the subject of speculation and hypotheses about their origins, their real functions, and importance, grasps the attention of researchers and scientists seeking to elucidate the behavior of human pathologies, aiming at subsequently develop methods of combat and the easing of its harmful or health effects. This part of the cell physiology has been showing the years limiting your paper is not the characteristic (separation of the core of the cytoplasm in which has specific frameworks for the regulation of the passage of sub- stances and withdrawals, which are (pores nuclear) and Yes being a very important agent in the emergence of syndromes and/or hereditary diseases, research in spite of their characteristics and composition are made from complex technological methods, currently in range of scholars providing means for deepening the information about the components of the actions of their proteins, how does your interaction with the LMNA genes present in the nuclear lamina (which helps in support of (EN)) being a vector for the appearance of pathologies.

It is then possible to say that there will still be discovered numerous relationships with many different human diseases, with a view to the lot which is still ignored on their functional characteristics.

\section{REFERENCES}

[1] KIERSZENBAUM A, TRES L. Histologia e biologia celular: uma introdução à patologia; (2016).

[2] MARQUES C. Oncologia: uma abordagem multidisciplinar. [s.l.] Carpe Diem; (2016).

[3] SULLIVAN T. (1999) 11. Loss of A-type lamin expression compromises nuclear envelope integrity leading to muscular dystrophy. The Journal of Cell Biology. 147(5):913-920.

[4] MAGISTRIS DE, P ANTONIN, W. (2018). The dynamic nature of the nuclear envelope. Current Biology. 28(8):487-497.

[5] LOWE JSS, Lowe. Histologia Humana; (2015).

[6] MÉNDEZ-LÓPEZ I, WORMAN HJ. (2012). Inner nuclear membrane proteins: impact on human disease. Chromosoma. 121(2):153-167.

[7] FRANÇA SCVA. Laminopatias: da fisiopatologia à terapêutica. set; (2016).

[8] BARROWMAN J. (2012). Requirements for Efficient Proteolytic Cleavage of Prelamin A by ZMPSTE24. PLOS ONE. 7(2):32120.

[9] MAURER M, LAMMERDING J. (2019). The Driving Force: Nuclear Mechanotransduction in Cellular Function, Fate, and Disease. Annual Review of Biomedical Engineering. 21(1).

[10] WORMAN HJ, ÖSTLUND C, WANG Y. Diseases of the nuclear envelope. Cold Spring Harbor perspectives in biology; (2010).

[11] MOUNKES L. (2003). The laminopathies: nuclear structure meets disease. Current opinion in genetics. \& development. 13(3):223-230.

[12] GARTLER SM. (2006). The chromosome number in humans: a brief history. Nature Reviews Genetics. 7(8):655.

[13] WATSON JD. Biologia Molecular do Gene; (2015).

[14] CHATZIFRANGKESKOU M, BONNE G, MUCHIR A. (2015). Nuclear envelope, and striated muscle diseases. Current opinion in cell biology. v. 32:1-6.

[15] CHANG F, LOAYZA DELGADO, E FERNANDEZ, Composición C. Abundancia y distribución del fitoplancton frente a la costa del Perú durante el verano; (1999).
[16] DUTTA S, BHATTACHARYYA M, SENGUPTA K. (2018). Changes in the Nuclear Envelope in Laminopathies. Advances in Experimental Medicine and Biology. p. 31-38.

[17] FISHER DZ, CHAUDHARY N, BLOBEL G; (1986). cDNA sequencing of nuclear lamins $\mathrm{A}$ and $\mathrm{C}$ reveals primary and secondary structural homology to intermediate filament proteins. vol. 83. p. 6450-6454.

[18] BONNE G, LETURCQ F, YAOU RB. Emery-Dreifuss muscular dystrophy. In: GeneReviews $®[$ Internet]. [s.l.] University of; (2015).

[19] EARLE AJ. Mutant lamins cause nuclear envelope rupture and DNA damage in skeletal muscle cells. Bio Rxiv; (2019).

[20] GERBINO A. Role of Lamin A/C Gene Mutations in the Signaling Defects Leading to Cardiomyopathies; (2018). Frontiers in Physiology, v. 9.

[21] HOUSTON MT, CAMERON AN, GUTIERREZ JB. (2018). A Review of Mathematical Models for Muscular Dystrophy: A Systems Biology Approach. PLOS Currents Muscular Dystrophy. 16.

[22] PANKUWEIT S. Lamin A/C mutations in patients with dilated cardiomyopathy. European heart journal; (2018).

[23] BAEK JH, MCKENNA T, ERIKSSON M. Hutchinson Gilford Progeria Syndrome. Genetic Disorders; (2013).

[24] KITTEN GT, NIGG EA. (1991). The CaaX motif is required for isoprenylation, carboxyl methylation, and nu- clear membrane association of lamin B2. The Journal of Cell Biology. 113(1):13-23.

[25] SANTIAGO CRESPO, D. Envoltura nuclear, laminopatías y envejecimiento acelerado. Revista Española de Geriatría y Gerontología; (2007).

[26] SOLHA GCF. Os genes interrompidos: introdução histórica ao impacto da descoberta dos íntrons (1977) na controvérsia sobre a definição de gene molecular clássico (1960); (2005).

[27] HASEGAWA M. (1999). Stereoselective analyses of selegiline metabolites: possible urinary markers for selegiline therapy. Forensic Science International. 101(2):95- 106.

[28] HERSHBERGER RE, MORALES A. Dilated cardiomyopathy overview. In: Genereviews® [internet]. [s.l.] University of; (2018).

[29] JAPP AG. (2016). The diagnosis and evaluation of dilated cardiomyopathy. Journal of the American College of Cadiology. 67(25):2996-3010.

[30] KITTLESON MD, KIENLE RD. Small animal cardiovascular medicine; (1998).

[31] WEINTRAUB RG, SEMSARIAN C, MACDONALD P. Dilated cardiomyopathy. The Lancet. 390(10092):400-414.

(2017)

[32] SCHOENWOLF S. Larsen embriologia humana; (2015).

[33] REED UC. (2002). Doenças neuromusculares. Jornal de Pediatria. 78:89-103.

[34] OLIVEIRA MDE. (2018). Experimental Planning Factorial. A Brief Review International Journal of Advanced Engineering Research and Science (IJAERS). 6495(6):166-177. 